\title{
Diet throughout childhood and age at menarche in a contemporary cohort of British girls
}

\author{
Imogen S Rogers ${ }^{1, *}$, Kate Northstone ${ }^{2}$, David B Dunger ${ }^{3}$, Ashley R Cooper ${ }^{4}$, \\ Andy R Ness ${ }^{5}$ and Pauline M Emmett ${ }^{6}$ \\ ${ }^{1}$ School of Pharmacy and Biomolecular Sciences, University of Brighton, Cockcroft Building, Lewes Road, \\ Brighton BN2 4GJ, UK: ${ }^{2}$ Department of Social Medicine, University of Bristol, Bristol, UK: ${ }^{3}$ Department of \\ Paediatrics, University of Cambridge, Addenbrookes Hospital, Cambridge, UK: ${ }^{4}$ Department of Exercise, \\ Nutrition and Health Sciences, University of Bristol, Bristol, UK: ${ }^{5}$ Department of Oral and Dental Science, \\ University of Bristol, Bristol, UK: ${ }^{6}$ Department of Community-based Medicine, University of Bristol, Bristol, UK
}

Submitted 5 August 2009: Accepted 13 April 2010: First published online 8 June 2010

\begin{abstract}
Objective: To investigate associations between dietary intakes throughout childhood and age at menarche, a possible indicator of future risk of disease, in a contemporary cohort of British girls.

Design: Diet was assessed by FFQ at 3 and 7 years of age, and by a 3 d unweighed food diary at 10 years. Age at menarche was categorised as before or after 12 years 8 months, a point close to the median age in this cohort.

Setting: Bristol, South-West England.

Subjects: Girls ( $n$ 3298) participating in the Avon Longitudinal Study of Parents and Children.

Results: Higher energy intakes at 10 years were positively associated with the early occurrence of menarche, but this association was removed on adjusting for body size. Total and animal protein intakes at 3 and 7 years were positively associated with age at menarche $\leq 12$ years 8 months (adjusted OR for a 1 SD increase in protein at 7 years: $1 \cdot 14(95 \%$ CI $1 \cdot 04,1 \cdot 26))$. Higher PUFA intakes at 3 and 7 years were also positively associated with early occurrence of menarche. Meat intake at 3 and 7 years was strongly positively associated with reaching menarche by 12 years 8 months (OR for menarche in the highest $v$. lowest category of meat consumption at 7 years: $1 \cdot 75$ (95\% CI 1.25, 2.44)).

Conclusions: These data suggest that higher intakes of protein and meat in early to mid-childhood may lead to earlier menarche. This may have implications for the lifetime risk of breast cancer and osteoporosis.
\end{abstract}

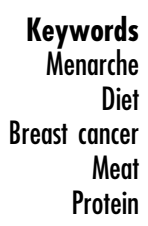

During the 20th century there was a dramatic fall in the age at menarche (AAM), widely attributed to improvements in nutrition. However, during the last 30 years or so there has been a levelling and even a slight reversal of this trend, despite increasing rates of childhood obesity. Earlier menarche is associated with an increased risk of developing breast cancer ${ }^{(1-3)}$, possibly as a result of increased lifetime exposure to oestrogens. Studies have found that women who started menstruating at or before 12 years of age have an odds ratio for breast cancer of about $1 \cdot 5-2 \cdot 0$ compared with those started aged 15 years or more ${ }^{(4,5)}$. Early menarche may also be associated with an increased risk of ovarian cancer and $\mathrm{IHD}^{(6)}$, but is protective against osteoporosis ${ }^{(7)}$, a major cause of morbidity and mortality. Identifying factors associated with early menarche may promote a better understanding of the aetiology of these diseases, and understanding the role of modifiable factors such as diet is particularly important.

Although it is known that anorexia nervosa and undernutrition can delay menarche ${ }^{(8,9)}$, the relationship between normal ranges of childhood dietary intakes and AAM is unclear. Associations observed between energy intake and AAM are variable ${ }^{(10-15)}$ and hard to compare between studies due to inconsistent adjustment for body size and for under-reporting by obese subjects. Fat intake affects oestrogen metabolism ${ }^{(16)}$ and has been suggested as a possible risk factor for breast cancer, thus potentially providing a link with AAM, but there is no consistent evidence that intakes of either total fat or different types of fat are associated with $\mathrm{AAM}^{(10,12-14)}$. Dietary fibre intakes relate to plasma oestrogen concentrations ${ }^{(17,18)}$ and international variations in fibre intake correlate with differences in $\mathrm{AAM}^{(19)}$. Foods suggested to affect breast 
cancer risk and therefore of interest in relation to possible associations with AAM include meat ${ }^{(20)}$ and soya products. Soya is a rich source of phyto-oestrogens, which may exert either pro- or anti-oestrogenic effects. Various micronutrients ${ }^{(10,21)}$, vegetarian diets and nuts and seeds ${ }^{(22)}$ have also been implicated in the timing of puberty.

Most existing studies of diet and menarche have measured diet close to or after the occurrence of menarche, making it hard to draw conclusions about the causality of any observed relationships with diet. The critical period for diet to impact on pubertal timing may be many years earlier, as suggested by the recently demonstrated associations between early growth and $\mathrm{AAM}^{(23,24)}$. Many studies lack information on important potential confounding factors. Moreover, most have investigated macronutrient intakes only and few present information on the intakes of micronutrients or food groups.

The aim of the current study was to relate dietary intakes measured prospectively throughout childhood to the occurrence of menarche in a large population of girls in South-West England.

\section{Methods}

\section{Study population}

The Avon Longitudinal Study of Parents and Children (ALSPAC) is an ongoing prospective cohort study recruited from all pregnancies in three Bristol-based District Health Authorities with expected dates of delivery between April 1991 and December 1992. A total cohort of 14541 pregnancies resulted. Ethical approval for the study was obtained from the ALSPAC Law and Ethics Committee and the local research ethics committees. More detailed information on the study ${ }^{(25)}$ is available on the ALSPAC website (http://www.bristol.ac.uk/alspac). Data have been collected on the parents and their children primarily using questionnaires alongside medical records, biological samples and clinical data. From the age of 7 years all children have been invited to regular research clinics for a variety of clinical assessments. The present study relates to AAM and so looks at girls only.

\section{Assessment of age at menarche}

Data on whether or not the girls had started menstruating was collected at clinics run when they were aged about 11.5 years and about 12.5 years. The latter was held between February 2004 and December 2005; the girls were asked during a measuring session in a private room if they had started menstruating, and if so when.

In total 3751 girls attended the clinic at $12 \cdot 5$ years. Mean (SD) age of attendance at the clinic was $12 \cdot 89(0 \cdot 23)$ years, ranging from 11.30 to 14.34 years. Data were available from 3298 girls on whether or not they had reached menarche; of these 1637 (50\%) stated that they had not. Of the 1661 who had reached menarche, age at

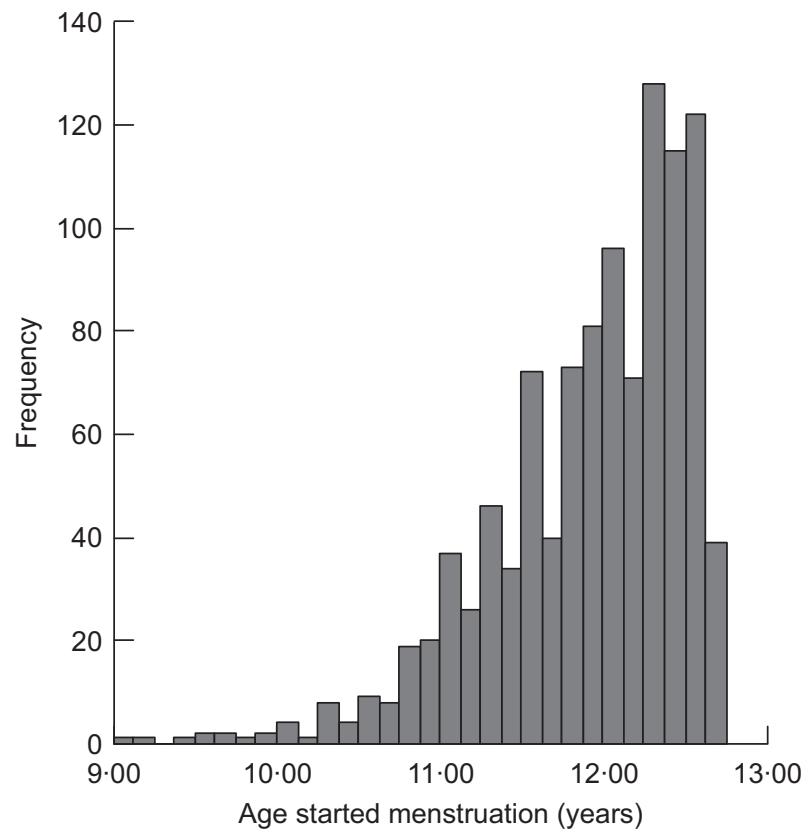

Fig. 1 Distribution of age at menarche among girls who had reached menarche by 12 years 8 months, Avon Longitudinal Study of Parents and Children, Bristol, South-West England

first period was available for 1550 and for 1328 white girls from singleton births. Due to the range of ages at which the girls attended the clinic and the fact that $50 \%$ of girls had not yet reached menarche on attending, it was not possible to determine median age at menarche. Thus 12 years 8 months was chosen as a cut-off point for AAM which was likely to be as near as possible to the median, i.e. old enough to maximise the number of girls in the 'yes' group for menarche, but young enough to minimise the amount of missing data resulting from girls who had not yet started menstruating but attended the clinic at ages younger than the cut-off point. Figure 1 shows the distribution of age at first period among those girls who reached menarche by 12 years 8 months ( $n$ 1043). Girls reaching menarche after 12 years 8 months do not appear in this figure, as data on AAM later than 12 years 8 months are available only on some of those girls attending the clinic late. Some descriptive characteristics of girls with and without data on AAM are given in Table 1. Compared with the whole cohort, girls with data on AAM were less likely to have a mother whose periods started before 12 years of age, a mother with no educational qualifications and a father in social class IV or V. They had higher birth weight, but were shorter and had a lower BMI at 10 years. They were more likely to have been breast-fed and less likely to have received solid foods before 3 months of age, and had a marginally higher energy intake at 10 years.

\section{Assessment of diet}

The dietary information used in the present study was collected by two methods: 3 d dietary record and FFQ. 
Table 1 Descriptive characteristics of girls with and without data on age at reaching menarche (baseline group for comparison = live births in the ALSPAC cohort), Avon Longitudinal Study of Parents and Children, Bristol, South-West England

\begin{tabular}{|c|c|c|c|c|c|}
\hline & \multicolumn{2}{|c|}{$\begin{array}{l}\text { With data } \\
\text { (n 3298) }\end{array}$} & \multicolumn{2}{|c|}{$\begin{array}{l}\text { Without data } \\
\quad(n 3758)\end{array}$} & \multirow[b]{2}{*}{$P$ value } \\
\hline & Mean & SD & Mean & SD & \\
\hline Birth weight (g) & 3362 & 507 & 3315 & 547 & $<0.0001 \S$ \\
\hline Weight at 10 years $(\mathrm{kg})$ & $38 \cdot 3$ & $8 \cdot 7$ & $39 \cdot 8$ & $10 \cdot 1$ & $<0.0001 \S$ \\
\hline Height at 10 years $(\mathrm{cm})$ & $144 \cdot 1$ & $7 \cdot 0$ & $144 \cdot 6$ & $7 \cdot 0$ & $<0.0004 \S$ \\
\hline BMI at 10 years $\left(\mathrm{kg} / \mathrm{m}^{2}\right)$ & $18 \cdot 3$ & $3 \cdot 2$ & $18 \cdot 8$ & $3 \cdot 7$ & $0.001 \S$ \\
\hline \multirow[t]{2}{*}{ Energy intake at 10 years (MJ) } & $7 \cdot 4$ & $1 \cdot \overline{5}$ & $7 \cdot 3$ & $1 \cdot 5$ & $0.034 \S$ \\
\hline & $n$ & $\%$ & $n$ & $\%$ & \\
\hline \multicolumn{6}{|l|}{ Maternal education } \\
\hline CSE & 387 & $12 \cdot 9$ & 806 & $26 \cdot 8$ & $<0.0001 \|$ \\
\hline Vocational* $^{*}$ & 250 & $8 \cdot 3$ & 338 & $11 \cdot 2$ & \\
\hline O levelt & 1050 & $35 \cdot 0$ & 1032 & $34 \cdot 3$ & \\
\hline$>0$ level & 1311 & $43 \cdot 7$ & 837 & $27 \cdot 8$ & \\
\hline \multicolumn{6}{|l|}{ Paternal social class } \\
\hline I & 349 & $12 \cdot 6$ & 220 & $8 \cdot 6$ & $<0.0001 \|$ \\
\hline II & 999 & $35 \cdot 9$ & 829 & $32 \cdot 2$ & \\
\hline IIINM & 343 & $12 \cdot 3$ & 236 & $9 \cdot 2$ & \\
\hline IIIM & 774 & $27 \cdot 9$ & 904 & $35 \cdot \overline{2}$ & \\
\hline IV/V & 314 & $11 \cdot 3$ & 382 & $14 \cdot 9$ & \\
\hline \multicolumn{6}{|l|}{ Parity } \\
\hline 0 & 1431 & $47 \cdot 6$ & 1393 & $42 \cdot 7$ & $<0.0001 \|$ \\
\hline 1 & 1076 & $35 \cdot 8$ & 1119 & $34 \cdot 3$ & \\
\hline$\geq 2$ & 497 & $16 \cdot 5$ & 750 & $23 \cdot 0$ & \\
\hline \multicolumn{6}{|l|}{ Maternal age at menarche (years) } \\
\hline$\leq 10$ & 89 & $3 \cdot 3$ & 151 & $5 \cdot 6$ & $<0.0001 \|$ \\
\hline 11 & 391 & $14 \cdot 4$ & 450 & $16 \cdot 6$ & \\
\hline 12 & 588 & $21 \cdot 7$ & 546 & $20 \cdot 2$ & \\
\hline 13 & 804 & $29 \cdot 7$ & 776 & $28 \cdot 7$ & \\
\hline 14 & 480 & $17 \cdot 7$ & 432 & $16 \cdot 0$ & \\
\hline 15 & 222 & $8 \cdot 2$ & 225 & $8 \cdot 3$ & \\
\hline$\geq 16$ & 135 & $5 \cdot 0$ & 125 & $4 \cdot 6$ & \\
\hline \multicolumn{6}{|l|}{ Breast-feeding duration } \\
\hline Never & 562 & $19 \cdot 7$ & 808 & $33 \cdot 3$ & $<0.0001 \|$ \\
\hline$<6$ months & 1119 & $39 \cdot 2$ & 927 & $38 \cdot 2$ & \\
\hline$\geq 6$ months & 1172 & $41 \cdot 1$ & 690 & $28 \cdot \overline{5}$ & \\
\hline \multicolumn{6}{|l|}{ Age of introduction to solids } \\
\hline$\leq 2$ months & 329 & $11 \cdot 3$ & 412 & $16 \cdot 0$ & $<0.0001 \|$ \\
\hline 3 months & 1646 & $56 \cdot 6$ & 1433 & $55 \cdot 7$ & \\
\hline 4 months & 786 & $27 \cdot 0$ & 605 & $23 \cdot 5$ & \\
\hline$\geq 5$ months & 145 & 5.0 & 125 & 4.9 & \\
\hline
\end{tabular}

*Lower level national school exams at age 16 years.

tHigher level national school exams at age 16 years

$\ddagger A$ level (national school exams at age 18 years) or university degree.

$\S P$ value by $t$ test.

$\| P$ value by $\chi^{2}$ test.

The $3 \mathrm{~d}$ dietary records were collected from the whole cohort between February 2002 and October 2003 when the child was aged 10-11 years. Around a week before the child was due to visit a research clinic at the age of $10 \cdot 5$ years, a $3 \mathrm{~d}$ food diary was sent to the child to complete at home (for one weekend day and two weekdays) and bring to the clinic. The diary was checked by a nutritionist in the clinic for completeness and clarity, with the child and usually a parent. If the child had not completed a diary, a single $24 \mathrm{~h}$ recall was administered in the clinic. The diet records were coded using DIDO (Diet In, Data Out), a coding package developed by the MRC Human Nutrition Research Unit in Cambridge and adapted for use in coding children's diets ${ }^{(26)}$. The coded data were converted to nutrient intakes using a database consisting of the fifth edition of McCance \& Widdowson's The Composition of Foods and supplements ${ }^{(27-36)}$, augmented with manufacturers' information and information from the nutrient database used by the National Diet and Nutrition Survey.

Dietary information on the whole cohort was also collected by FFQ at 3 years ( 38 months) and 7 years ( 81 months), which were completed by the child's main carer. The questionnaires included questions about the weekly frequency of consumption of about sixty food groups and food items; there were five frequency options ranging from 'never or rarely' to 'more than once a day'. Standard portion sizes were used. These questionnaires were used to estimate nutrient intakes by multiplying the weekly frequency of consumption of each type of food by its estimated nutrient content, and summing this across all 
foods consumed. FFQ giving unrealistic estimates of any nutrient intakes were excluded from analyses. The questionnaires used are available on the ALSPAC website. The FFQ were validated by comparison with the results of $3 \mathrm{~d}$ food records taken on a $10 \%$ sub-sample of the cohort at 3 years and 7 years. Similar mean nutrient intakes were obtained by both methods, and correlations between nutrient intakes obtained by both methods were generally about 0.3 for absolute nutrient intakes and about $0 \cdot 4$ for nutrient intakes per MJ (see Appendix 1 and Appendix 2).

\section{Otber variables}

Data were also collected on several other variables considered to be potential confounders of any associations between diet and menarche. These included child's ethnic group, maternal educational level, paternal occupational social class, maternal smoking during pregnancy and maternal AAM (assessed by self-completion postal questionnaires sent to the mother during pregnancy), breast-feeding duration and age of introduction to solids (assessed by questionnaires sent to the mothers when the child was 6 months and 15 months old), and birth weight (extracted from routine hospital birth records). Ethnic group was classified as white/non-white; the non-white group of girls was too small ( $n$ 109) and ethnically heterogeneous to allow a more detailed classification of ethnic group. The other variables were classified as shown in Table 1. Height and weight were measured at the 10 years clinic and at the 7 years clinic held between September 1998 and September 2000 when the children were aged $7-8$ years. BMI was calculated as weight (in kilograms) divided by the square of height (in metres).

Among white singleton girls on whom data on whether or not menarche had occurred by 12 years 8 months were available, data on maternal education were also available for $98 \%$, on paternal social class for $88 \%$, on parity for $97 \%$, on maternal age at menarche for $98 \%$, on breastfeeding duration for $94 \%$, on age at introduction of solids on $95 \%$, and on height and BMI at 10 years for $92 \%$. The number included in each analysis is given in the tables.

\section{Statistical metbods}

The girls were divided into groups according to whether or not they had reached menarche by 12 years 8 months. Girls younger than 12 years 8 months at the second clinic visit who were still pre-menarche were excluded from the analyses.

Initial analyses suggested that the proportion of white and non-white girls reaching menarche by 12 years 8 months differed $\left(\chi^{2}=3 \cdot 50, P=0 \cdot 061\right)$, with more non-white than white girls reaching menarche by this age (49.5\% v. 40.6\%). As the total number of non-white girls ( $n$ 109) was too small to analyse separately, all subsequent analyses were restricted to white girls from singleton births.

The relationship between nutrient intakes and AAM was investigated initially by comparing nutrient intakes in girls who had and had not reached menarche using unpaired $t$ tests. Where necessary, nutrient intake distributions were transformed to the natural logarithm or the square root in order to minimize skewness in the distribution. Nutrient intakes (other than energy) were adjusted for energy intake using the residuals method ${ }^{(37)}$. For those nutrient intakes where there was some evidence of an association with $\operatorname{AAM}(P<0 \cdot 10)$, the odds ratios for menarche associated with a 1 SD increase in energy-adjusted nutrient intake were calculated using binary logistic regression, with and without adjustment for potential confounders. Nutrient intakes investigated were energy, total fat, SFA, MUFA and PUFA, starch, sugar, total, animal and vegetable protein, NSP (a measure of fibre intake), $\mathrm{Fe}, \mathrm{Ca}, \mathrm{Zn}, \mathrm{Mg}$ and carotene.

The association between food intakes at 3 years, 7 years and 10 years and the occurrence of menarche by 12 years 8 months was investigated initially using the $\chi^{2}$ test. At 3 years and 7 years food intakes were grouped by frequency of consumption, and at 10 years by mean daily amount consumed. Food variables investigated included intakes of fruit, vegetables, total and oily fish, meat, dairy products, soya meat/textured vegetable protein, legumes and whether or not the child ate a vegetarian diet (if no meat or fish consumption was reported in the FFQ or food diary, then the child was considered to be a vegetarian). The effect of potential confounders on any associations with food intake found in univariate analyses was investigated using binary logistic regression. To exclude the possibility that any observed relationships with diet merely reflected variation in body size, we also adjusted any associations found with diet at 10 years for height and BMI measured at 10 years, and any associations found with diet measured at 7 years for height and BMI measured at 7 years. No suitable measures of body size were available close to the 3 years diet measurements.

Analyses using dietary record data at 10 years were repeated excluding those children considered to be possible under-reporters on the basis of the agreement between estimated energy requirements (EER) based on age and body weight ${ }^{(38)}$ and reported energy intake $(\mathrm{REI})^{(39)}$; under-reporters were defined as subjects with a ratio of REI:EER of less than $78 \%$. (Only $3.6 \%$ of the sample were considered to be possible over-reporters, i.e. an REI of $>122 \%$ of EER.) Under-reporting was more likely among overweight children and children of lesseducated mothers. Analyses were also repeated excluding children for whom only $24 \mathrm{~h}$ recall data were available.

\section{Results}

\section{Food and nutrient intakes througbout childbood and occurrence of menarche}

Table 2 shows mean nutrient intakes according to the occurrence of menarche by 12 years 8 months, and Table 3 shows the adjusted and unadjusted odds ratios for 
Table 2 Mean/geometric mean energy and energy-adjusted nutrient intakes (and $95 \%$ confidence intervals) throughout childhood according to whether menarche was reached before or after 12 years 8 months, Avon Longitudinal Study of Parents and Children, Bristol, South-West England

\begin{tabular}{|c|c|c|c|c|c|c|}
\hline \multirow[b]{3}{*}{ Nutrient } & \multirow[b]{3}{*}{ Age of diet measurement } & \multicolumn{4}{|c|}{ Menarche by 12 years 8 months } & \multirow[b]{3}{*}{$P$ value } \\
\hline & & \multicolumn{2}{|c|}{ No } & \multicolumn{2}{|c|}{ Yes } & \\
\hline & & Mean & $95 \% \mathrm{Cl}$ & Mean & $95 \% \mathrm{Cl}$ & \\
\hline Energyt (MJ) & $\begin{array}{l}10 \text { years (incl. UR) } \\
10 \text { years (excl. UR) }\end{array}$ & $\begin{array}{l}7 \cdot 28 \\
7 \cdot 88\end{array}$ & $\begin{array}{l}7 \cdot 21,7 \cdot 36 \\
7 \cdot 81,7 \cdot 95\end{array}$ & $\begin{array}{l}7 \cdot 46 \\
8 \cdot 26\end{array}$ & $\begin{array}{l}7 \cdot 37,7 \cdot 55 \\
8 \cdot 18,8 \cdot 35\end{array}$ & $\begin{array}{r}0.002 \\
<0.001\end{array}$ \\
\hline PUFAt (g) & $\begin{array}{l}10 \text { years (incl. UR) } \\
10 \text { years (excl. UR) } \\
7 \text { years } \\
3 \text { years }\end{array}$ & $\begin{array}{l}11 \cdot 1 \\
11 \cdot 1 \\
12 \cdot 8 \\
6 \cdot 49\end{array}$ & $\begin{array}{l}10 \cdot 9,11 \cdot 3 \\
10 \cdot 9,11 \cdot 3 \\
12 \cdot 5,13 \cdot 4 \\
6 \cdot 41,6 \cdot 57\end{array}$ & $\begin{array}{l}11 \cdot 3 \\
11 \cdot 4 \\
13 \cdot 3 \\
6 \cdot 60\end{array}$ & $\begin{array}{l}11 \cdot 1,11 \cdot 5 \\
11 \cdot 1,11 \cdot 6 \\
12 \cdot 9,13 \cdot 6 \\
6 \cdot 51,6 \cdot 70\end{array}$ & $\begin{array}{l}0.103 \\
0.057 \\
0.019 \\
0.065\end{array}$ \\
\hline Protein $\ddagger(\mathrm{g})$ & $\begin{array}{l}7 \text { years } \\
3 \text { years }\end{array}$ & $\begin{array}{l}63 \cdot 9 \\
45 \cdot 6\end{array}$ & $\begin{array}{l}63 \cdot 5,64 \cdot 4 \\
45 \cdot 3,46 \cdot 0\end{array}$ & $\begin{array}{l}65 \cdot 1 \\
46 \cdot 2\end{array}$ & $\begin{array}{l}64 \cdot 6,65 \cdot 6 \\
45 \cdot 8,46 \cdot 6\end{array}$ & $\begin{array}{r}<0.001 \\
0.042\end{array}$ \\
\hline Animal protein§ (g) & $\begin{array}{l}7 \text { years } \\
3 \text { years }\end{array}$ & $\begin{array}{l}41 \cdot 0 \\
29 \cdot 5\end{array}$ & $\begin{array}{l}40 \cdot 5,41 \cdot 4 \\
29 \cdot 1,29 \cdot 8\end{array}$ & $\begin{array}{l}42 \cdot 4 \\
30 \cdot 1\end{array}$ & $\begin{array}{l}41 \cdot 8,43 \cdot 0 \\
29 \cdot 7,30 \cdot 6\end{array}$ & $\begin{array}{r}<0.001 \\
0.016\end{array}$ \\
\hline $\operatorname{Mg}($ (mg) & 10 years & 197 & 196,199 & 200 & 197, 202 & 0.084 \\
\hline $\mathrm{Zn} \S(\mathrm{mg})$ & 7 years & $6 \cdot 69$ & $6 \cdot 64,6 \cdot 74$ & $6 \cdot 79$ & $6 \cdot 73,6 \cdot 85$ & 0.021 \\
\hline Carotene $(\mu \mathrm{g})$ & 3 years & 1432 & 1391,1473 & 1508 & 1459,1558 & $0 \cdot 021 \|$ \\
\hline
\end{tabular}

UR, under-reporters.

Sample size according to whether menarche was reached before or after 12 years 8 months: $n 1486$ for 'no' and $n 1014$ for 'yes' including UR, and $n 1067$ for 'no' and $n 619$ for 'yes' excluding UR, for diet at 10 years; $n 1419$ for 'no' and $n 951$ for 'yes' for diet at 7 years; $n 1480$ for 'no' and $n 994$ for 'yes' for diet at 3 years.

${ }^{*} P$ value by $t$ test.

tGeometric mean shown, as nutrient intakes transformed to the natural logarithm before analysis.

¥Geometric mean shown, as nutrient intakes at 7 years transformed to the square root and nutrient intakes at 3 years transformed to the natural logarithm before analysis.

$\S$ Geometric mean shown, as nutrient intakes transformed to the square root before analysis.

$\| P$ value by Mann-Whitney $U$ test.

menarche per $1 \mathrm{sD}$ increase in nutrient intake at 3,7 and 10 years. Only those nutrients where there was some evidence $(P<0 \cdot 10)$ of an association with menarche are shown (full tables of results are available from the corresponding author). Adjustment for potential confounders generally had a minimal effect on any associations found.

Energy intakes at 10 years were higher in girls reaching menarche by 12 years 8 months, as might be expected given their greater height and weight at 10 years. Energy intake was also strongly positively associated with the OR for menarche. These associations with energy intake were strengthened on excluding under-reporters (adjusted OR: $1 \cdot 16$ per $1 \mathrm{sD}$ increase in energy intake at 10 years, rising to 1.54 on exclusion of under-reporters), but were eliminated on adjusting for height and BMI at 10 years. Energy intakes at 3 years and 7 years were not associated with AAM.

PUFA intakes at 7 years and 3 years were marginally higher among girls who reached menarche by 12 years 8 months, and were also marginally higher at 10 years on excluding under-reporters. PUFA intakes at 10 years, 7 years and 3 years were also weakly positively associated with the OR for menarche. Adjusting for height and BMI eliminated the association with PUFA at 10 years. There was no evidence of an association with intakes of total fat, SFA or MUFA.

Total and animal protein intakes at 3 years and 7 years, but not 10 years, were higher among girls who reached menarche by 12 years 8 months and were also positively associated with the OR for menarche. These associations were strongest for protein intakes at 7 years. There was no evidence for an association with vegetable protein intake, or that starch, sugar or NSP intakes at any age were associated with AAM.

$\mathrm{Mg}$ intakes at 10 years were marginally higher among girls who reached menarche by 12 years 8 months, and were weakly associated with the OR for menarche. Zn intakes at 7 years were higher among girls reaching menarche by 12 years 8 months, and were positively associated with the OR for menarche, and the same was true for carotene intakes at 3 years. There was no association with intakes of these nutrients at other ages or with $\mathrm{Ca}$ or $\mathrm{Fe}$ intakes at any age.

The associations between intakes at 7 years of PUFA, protein, animal protein and $\mathrm{Zn}$ and occurrence of menarche were minimally altered by adjustment for height and BMI at 7 years.

Exclusion of children with $24 \mathrm{~h}$ recall data only on diet at 10 years had a minimal effect on associations between dietary intakes and AAM.

Table 4 shows the incidence of menarche by 12 years 8 months according to food intakes throughout childhood and the OR for reaching menarche by category of food intake. Only those foods where there was some evidence $(P<0 \cdot 10)$ of an association with menarche are shown 
Table 3 Odds ratios (and $95 \%$ confidence intervals) for reaching menarche by 12 years 8 months per 1 SD increase in energy and energyadjusted nutrient intakes at 10 years, 7 years and 3 years, Avon Longitudinal Study of Parents and Children, Bristol, South-West England

\begin{tabular}{|c|c|c|c|c|c|c|}
\hline Nutrient & Age & Model & $n$ & $\mathrm{OR}^{*}$ & $95 \% \mathrm{Cl}$ & $P$ value* \\
\hline Energy & $\begin{array}{l}10 \text { years (incl. UR) } \\
10 \text { years (excl. UR) }\end{array}$ & $\begin{array}{l}\text { Unadjusted } \\
\text { Model } 1 \\
\text { Model } 2 \\
\text { Unadjusted } \\
\text { Model } 1 \\
\text { Model } 2\end{array}$ & $\begin{array}{l}2500 \\
2017 \\
2465 \\
1686 \\
1380 \\
1672\end{array}$ & $\begin{array}{l}1 \cdot 13 \\
1 \cdot 16 \\
0.99 \\
1.54 \\
1.53 \\
0.93\end{array}$ & $\begin{array}{l}1.05,1.23 \\
1.06,1.28 \\
0.90,1.08 \\
1.35,1.76 \\
1.31,1.78 \\
0.79,1.09\end{array}$ & $\begin{array}{r}0.002 \\
0.002 \\
0.770 \\
<0.001 \\
<0.001 \\
0.355\end{array}$ \\
\hline PUFA & $\begin{array}{l}10 \text { years (incl. UR) } \\
10 \text { years (excl. UR) } \\
7 \text { years } \\
3 \text { years }\end{array}$ & $\begin{array}{l}\text { Unadjusted } \\
\text { Model } 1 \\
\text { Model } 2 \\
\text { Unadjusted } \\
\text { Model 1 } \\
\text { Model } 2 \\
\text { Unadjusted } \\
\text { Model } 1 \\
\text { Model } 2 \\
\text { Unadjusted } \\
\text { Model } 1\end{array}$ & $\begin{array}{l}2500 \\
2017 \\
2465 \\
1686 \\
1380 \\
1672 \\
2370 \\
1956 \\
2187 \\
2474 \\
2040\end{array}$ & $\begin{array}{l}1 \cdot 07 \\
1 \cdot 09 \\
1 \cdot 01 \\
1 \cdot 10 \\
1 \cdot 10 \\
1 \cdot 07 \\
1 \cdot 10 \\
1 \cdot 09 \\
1 \cdot 11 \\
1 \cdot 08 \\
1 \cdot 13\end{array}$ & $\begin{array}{l}0.99,1 \cdot 16 \\
0.99,1 \cdot 20 \\
0.93,1 \cdot 11 \\
1.00,1 \cdot 22 \\
0.98,1.24 \\
0.95,1 \cdot 19 \\
1.02,1.20 \\
0.99,1 \cdot 20 \\
1.02,1.21 \\
1.00,1 \cdot 18 \\
1.02,1.24\end{array}$ & $\begin{array}{l}0.108 \\
0.066 \\
0.805 \\
0.058 \\
0.123 \\
0.254 \\
0.020 \\
0.066 \\
0.023 \\
0.065 \\
0.020\end{array}$ \\
\hline Protein & $\begin{array}{l}7 \text { years } \\
3 \text { years }\end{array}$ & $\begin{array}{l}\text { Unadjusted } \\
\text { Model } 1 \\
\text { Model } 2 \\
\text { Unadjusted } \\
\text { Model } 1\end{array}$ & $\begin{array}{l}2370 \\
1956 \\
2187 \\
2474 \\
2040\end{array}$ & $\begin{array}{l}1 \cdot 16 \\
1 \cdot 14 \\
1 \cdot 15 \\
1 \cdot 10 \\
1 \cdot 11\end{array}$ & $\begin{array}{l}1 \cdot 07,1 \cdot 26 \\
1 \cdot 04,1 \cdot 26 \\
1 \cdot 06,1 \cdot 26 \\
1 \cdot 00,1 \cdot 20 \\
1 \cdot 00,1 \cdot 23\end{array}$ & $\begin{array}{r}<0.001 \\
0.007 \\
0.002 \\
0.042 \\
0.057\end{array}$ \\
\hline Animal protein & $\begin{array}{l}7 \text { years } \\
3 \text { years }\end{array}$ & $\begin{array}{l}\text { Unadjusted } \\
\text { Model } 1 \\
\text { Model } 2 \\
\text { Unadjusted } \\
\text { Model } 1\end{array}$ & $\begin{array}{l}2370 \\
1956 \\
2187 \\
2474 \\
2040\end{array}$ & $\begin{array}{l}1 \cdot 17 \\
1 \cdot 15 \\
1 \cdot 17 \\
1 \cdot 11 \\
1 \cdot 09\end{array}$ & $\begin{array}{l}1 \cdot 08,1 \cdot 28 \\
1 \cdot 04,1 \cdot 26 \\
1 \cdot 07,1 \cdot 28 \\
1 \cdot 02,1 \cdot 21 \\
0.99,1 \cdot 21\end{array}$ & $\begin{array}{r}<0.001 \\
0.005 \\
0.001 \\
0.016 \\
0.085\end{array}$ \\
\hline $\mathrm{Mg}$ & $\begin{array}{l}10 \text { years (incl. UR) } \\
10 \text { years (excl. UR) }\end{array}$ & $\begin{array}{l}\text { Unadjusted } \\
\text { Model } 1 \\
\text { Model } 2 \\
\text { Unadjusted } \\
\text { Model } 1 \\
\text { Model } 2\end{array}$ & $\begin{array}{l}2500 \\
2017 \\
2465 \\
1686 \\
1380 \\
1672\end{array}$ & $\begin{array}{l}1 \cdot 07 \\
1 \cdot 09 \\
1 \cdot 09 \\
1 \cdot 07 \\
1 \cdot 08 \\
1 \cdot 10\end{array}$ & $\begin{array}{l}0.99,1 \cdot 16 \\
0.99,1 \cdot 19 \\
1.00,1 \cdot 19 \\
0.97,1 \cdot 18 \\
0.96,1.21 \\
0.99,1.23\end{array}$ & $\begin{array}{l}0.084 \\
0.085 \\
0.048 \\
0.193 \\
0.232 \\
0.077\end{array}$ \\
\hline $\mathrm{Zn}$ & 7 years & $\begin{array}{l}\text { Unadjusted } \\
\text { Model } 1 \\
\text { Model } 2\end{array}$ & $\begin{array}{l}2370 \\
1956 \\
2187\end{array}$ & $\begin{array}{l}1 \cdot 10 \\
1 \cdot 10 \\
1 \cdot 10\end{array}$ & $\begin{array}{l}1 \cdot 01,1 \cdot 20 \\
1 \cdot 00,1 \cdot 20 \\
1 \cdot 01,1 \cdot 21\end{array}$ & $\begin{array}{l}0.021 \\
0.058 \\
0.028\end{array}$ \\
\hline Carotene & 3 years & $\begin{array}{l}\text { Unadjusted } \\
\text { Model } 1\end{array}$ & $\begin{array}{l}2474 \\
2040\end{array}$ & $\begin{array}{l}1 \cdot 10 \\
1 \cdot 09\end{array}$ & $\begin{array}{l}1 \cdot 01,1 \cdot 19 \\
0.98,1 \cdot 80\end{array}$ & $\begin{array}{l}0.022 \\
0.058\end{array}$ \\
\hline
\end{tabular}

UR, under-reporters.

Model 1: adjusted for maternal education, paternal occupational social class, maternal smoking in pregnancy, maternal age at menarche, parity, duration of breast-feeding, age of introduction to solids and birth weight.

Model 2: adjusted only for height and BMI at time of diet measurement.

${ }^{*} \mathrm{OR}$ and $P$ value obtained by binary logistic regression.

(full tables of results are available from the corresponding author). Few associations between food intake and menarche were observed, but meat intakes at both 7 years and 3 years were strongly positively associated with the occurrence of menarche. At 7 years, the proportion reaching menarche by 12 years 8 months increased from $35 \cdot 2 \%$ among those eating less than 4 portions of meat per week to $48 \cdot 8 \%$ among those eating more than 12 portions, with the OR for menarche being 1.75 in those consuming more than 12 portions compared with $<4$ portions. There was also weak evidence that higher vegetable consumption at 3 years was positively associated with the occurrence of menarche.

There was no evidence that the incidence of menarche differed according to the intake at any age of fruit, total fish, oily fish, dairy products, soya products and legumes or between vegetarians and non-vegetarians.

These associations remained similar on adjustment for potential confounders and for body size around the time of diet measurement.

\section{Discussion}

In this large group of contemporary girls we have found a number of associations between dietary intakes throughout childhood and the occurrence of menarche. We have confirmed previous findings of higher energy intakes among girls reaching menarche earlier, reflecting their larger body size. We have also found evidence that 
Table 4 Odds ratios (and $95 \%$ confidence intervals) by binary logistic regression for reaching menarche by 12 years 8 months according to levels of food group consumption at 7 years and 3 years, Avon Longitudinal Study of Parents and Children, Bristol, South-West England

\begin{tabular}{|c|c|c|c|c|c|c|c|c|c|c|c|c|c|}
\hline \multirow[b]{3}{*}{ Food } & \multirow[b]{3}{*}{ Intake category } & \multicolumn{6}{|c|}{7 years } & \multicolumn{6}{|c|}{3 years } \\
\hline & & \multicolumn{2}{|c|}{ Reaching menarche } & \multicolumn{2}{|c|}{ Unadjusted } & \multicolumn{2}{|c|}{ Adjusted* } & \multicolumn{2}{|c|}{ Reaching menarche } & \multicolumn{2}{|c|}{ Unadjusted } & \multicolumn{2}{|c|}{ Adjusted* } \\
\hline & & $\%$ & $n$ & OR & $95 \% \mathrm{Cl}$ & OR & $95 \% \mathrm{Cl}$ & $\%$ & $n$ & OR & $95 \% \mathrm{Cl}$ & OR & $95 \% \mathrm{Cl}$ \\
\hline Meatt & $\begin{array}{l}1 \\
2 \\
3 \\
4 \\
5\end{array}$ & $\begin{array}{l}35 \cdot 2 \\
36 \cdot 4 \\
41 \cdot 4 \\
37 \cdot 6 \\
48 \cdot 8\end{array}$ & $\begin{array}{r}81 \\
171 \\
295 \\
217 \\
196\end{array}$ & $\begin{array}{c}1 \cdot 00 \\
1.05 \\
1.30 \\
1 \cdot 11 \\
1 \cdot 75 \\
P \S \text { tı }\end{array}$ & $\begin{array}{l}0 \cdot 76,1 \cdot 46 \\
0 \cdot 96,1 \cdot 77 \\
0 \cdot 81,1 \cdot 53 \\
1 \cdot 25,2 \cdot 44 \\
d=0.001 \\
2370)\end{array}$ & $\begin{array}{c}1.00 \\
0.91 \\
1.19 \\
0.96 \\
1.57 \\
P \S \mathrm{t}\end{array}$ & $\begin{array}{l}0 \cdot 62,1 \cdot 35 \\
0 \cdot 82,1 \cdot 72 \\
0 \cdot 65,1 \cdot 41 \\
1 \cdot 03,2 \cdot 37 \\
d=0 \cdot 020 \\
1956)\end{array}$ & $\begin{array}{l}35 \cdot 0 \\
36 \cdot 2 \\
39 \cdot 5 \\
43 \cdot 4 \\
43 \cdot 8\end{array}$ & $\begin{array}{r}99 \\
108 \\
341 \\
234 \\
225\end{array}$ & $\begin{array}{c}1.00 \\
1.06 \\
1.21 \\
1.43 \\
1.45 \\
P \S \text { tı }\end{array}$ & $\begin{array}{l}0.75,1 \cdot 48 \\
0.92,1.60 \\
1 \cdot 06,1.92 \\
1.07,1.95 \\
d=0 \cdot 002 \\
2474)\end{array}$ & $\begin{array}{c}1 \cdot 00 \\
1 \cdot 13 \\
1 \cdot 19 \\
1.35 \\
1.44 \\
P \S \text { tı }\end{array}$ & $\begin{array}{l}0.76,1.68 \\
0.86,1.67 \\
0.95,1.93 \\
1.00,2.08 \\
d=0.024 \\
2040)\end{array}$ \\
\hline Vegetablesł & $\begin{array}{l}1 \\
2 \\
3 \\
4 \\
5\end{array}$ & & & & & & & $\begin{array}{l}35 \cdot 6 \\
40 \cdot 3 \\
39 \cdot 5 \\
42 \cdot 2 \\
41 \cdot 6\end{array}$ & $\begin{array}{l}104 \\
156 \\
247 \\
288 \\
212\end{array}$ & $\begin{array}{c}1 \cdot 00 \\
1 \cdot 22 \\
1 \cdot 18 \\
1 \cdot 32 \\
1 \cdot 29 \\
P \S \mathrm{tt}\end{array}$ & $\begin{array}{l}0.89,1 \cdot 67 \\
0 \cdot 88,1 \cdot 57 \\
0.99,1 \cdot 75 \\
0.96,1 \cdot 73 \\
d=0.091 \\
2474)\end{array}$ & $\begin{array}{c}1.00 \\
1.26 \\
1.27 \\
1.33 \\
1.37 \\
P \S \mathrm{tr}\end{array}$ & $\begin{array}{l}0.88,1.81 \\
0.91,1.77 \\
0.95,1.84 \\
0.96,1.94 \\
d=0.109 \\
2040)\end{array}$ \\
\hline
\end{tabular}

*Adjusted for energy intake, maternal education, paternal occupational social class, maternal smoking in pregnancy, maternal age at menarche, parity, duration of breast-feeding, age of introduction to solids and birth weight.

tIntake categories for meat: at 7 years, $1=<4$ portions/week, $2=4-7$ portions/week, $3=>7-9$ portions/week, $4=>9-12$ portions/week, $5=>12$ portions/week; at 3 years, $1=<3$ portions/week, $2=3-4$ portions/ week, $3=>4-6$ portions/week, $4=>6-8$ portions/week, $5=>8$ portions/week.

3 years $1=<3$ portions/week, $2=3-6$ portions/week, $3=>6-<10$ portions/week, $4=10-<14$ portions/week, $5=\geq 14+$ portions/week $\S P$ for linear trend using food intake category as a covariate. 
intakes of meat and total and animal protein, and also possibly PUFA in early to mid-childhood may increase the chances of menarche by 12 years 8 months. However, we found no evidence that the chances of reaching menarche increased with higher total fat intakes, or reduced with higher intakes of fruit, vegetables or NSP. Unexpectedly, higher vegetable intakes at 3 years were associated with an increased chance of reaching menarche, although this may have reflected the positive association between meat and vegetable intakes at 3 years.

Strengths of our study include the large sample size and the prospectively collected data on diet in early and midchildhood as well as at 10 years, close to the time of menarche. Most other studies have collected data on diet only close to or after menarche, but the associations between early growth and pubertal development ${ }^{(23,24)}$ suggest that the critical exposures predicting puberty may occur earlier in childhood. In addition, measuring diet close to the time of puberty introduces the possibility of reverse causation, whereby puberty may affect dietary intakes rather than vice versa. This may have been an issue with our 10 years dietary data as many of the girls would have entered puberty by this point. A further strength is the wide range of foods and nutrients examined. Conversely, this will have increased the risk of false positive findings. However, several of the associations between dietary intakes and the occurrence of menarche were found for more than one age point throughout childhood, increasing their plausibility. It was also possible to control for a large range of potential confounding variables. This generally had a minimal effect on the strength of the associations, suggesting that the observed relationships with diet were unlikely to reflect unmeasured confounding.

Weaknesses of the study include the fact that the last point at which we were able to assess AAM was around 12 years 8 months, so we were unable to look at effects on mean AAM or create a 'late' menarche group. In addition the method of dietary assessment at 10 years differed from the method at 3 years and 7 years, limiting our ability to compare the results obtained at different time points. The dietary data at 3 years and 7 years were by obtained an unquantified FFQ and so results for energy intake at these ages should be treated with caution, although FFQ have a reasonable ability to rank individuals for energy-adjusted nutrient intakes and should discriminate well for frequency of consumption of different foods. Information on diet at 10 years was collected by a $3 \mathrm{~d}$ unweighed food record. Unweighed food records have been shown to compare well with the results from weighed intakes ${ }^{(40)}$, generally considered to be the 'gold standard' of dietary assessment, and results obtained by this method at earlier ages in ALSPAC have plausible relationships with biological outcomes such as Fe status ${ }^{(41)}$ and insulin-like growth factor-1 levels ${ }^{(42)}$. There was a relative lack of data on girls from lower socio-economic groups which may have restricted the range of dietary intakes observed and limited our ability to detect associations between diet and AAM. However, unless the observed associations differed according to social class, it is unlikely to have affected the generalizability of our results.

A study with comparable methods to our own was that of Berkey et al. ${ }^{(43)}$, who studied sixty-seven Caucasian girls born in Boston in the 1930s and 1940s. Diet was prospectively assessed at ages $1-2,3-5$ and $6-8$ years. AAM was related to intakes of energy and energy-adjusted intakes of fat, animal protein and vegetable protein. No association with energy or fat intake throughout childhood was found, but there was a negative association between mean AAM and animal protein intakes at 3-5 and 6-8 years, and a positive association with vegetable protein intakes at 3-5 years. These results are closely comparable to our own, despite the fact that the subjects were born during the Depression and maturing during World War II.

Several early studies also suggested that meat or protein intake had a menarche-promoting effect. In 1950 Kralj-Cercek $^{(44)}$ reported on a study of Slovenian girls whose diet was classified as 'proteinous', 'mixed' or 'carbohydratic', and found that the mean AAM increased from $12 \cdot 7$ years in the 'proteinous' group to $14 \cdot 1$ years in the 'carbohydratic' group. This association with diet seemed to be independent of the effect of 'body build'. Two studies of American girls in $1970^{(45)}$ and $1987^{(46)}$ found vegetarianism ${ }^{(45)}$ and higher consumption of 'meat analogues' or 'nuts and beans, ${ }^{,(46)}$ to be associated with delayed menarche, and meat intake in the upper $v$. the lower quartile to be associated with reaching menarche 6 months earlier. However, information on dietary assessment methods in these studies was scant, and there was no control for energy intake or anthropometry in the analyses. A recent study of AAM in North Korean refugees also reported that women stating a 'food preference' for meat, fish and dairy reported a lower AAM than those with a food preference for rice and starch or fruit and vegetables $^{(47)}$. In a cross-sectional study of 8-16-year-old Spanish schoolgirls published in 1995 , Soriguer et al. ${ }^{(22)}$ also found that higher intakes of nuts (and seeds) were associated with a reduced risk of menarche, but found no association with meat intake. A large retrospective study of UK vegetarians in the 1990s found no difference in AAM between life-long vegetarians and those becoming vegetarian as adults ${ }^{(48)}$. Several other later studies which measured protein intake around the time of menarche found little evidence of an association ${ }^{(10-15)}$.

These differing results may stem from the relationship between meat and protein intake in the samples studied. It is possible that in historical cohorts (and the North Korean group) lower meat intake would have been associated with greater reductions in protein intake than today, when meat intake is more likely to be replaced with other protein sources. In our study, vegetarians had 
lower protein intakes, and meat and protein intakes were positively correlated. However, there was no difference between vegetarians and omnivores in the proportion reaching menarche, suggesting that the effect of meat or protein may be manifested at higher intakes and obscured by grouping all meat eaters together. A menarche-promoting role of meat/animal protein would seem logical from an evolutionary standpoint. Meat is a good source of bioavailable $\mathrm{Zn}$ and $\mathrm{Fe}$, requirements for which are high during pregnancy, and deficiencies of $\mathrm{Zn}$ and Fe are common among pregnant women in developing countries ${ }^{(49,50)}$. A meat-rich diet could be seen as indicating suitable nutritional conditions for a successful pregnancy. The secular trends in AAM in the West over the last century might reflect the secular trends in meat consumption.

In summary, in this contemporary population there was evidence that higher intakes of meat and protein might have a menarche-promoting effect, and that diet in early to mid-childhood may be more strongly associated with the occurrence of menarche than diet in later childhood. This implies that dietary alterations in early to mid-childhood might affect menarcheal timing, and possibly breast cancer and osteoporosis risk in later life. However, these findings need to be repeated in other populations before any recommendations for dietary change can be made.

\section{Acknowledgements}

Sources of funding: The UK Medical Research Council (grant ref. 74882), the Wellcome Trust (grant ref. 076467) and the University of Bristol provide core support for ALSPAC. The work on diet is further supported by the Arthritic Association. The present work was funded by a grant from the World Cancer Research Fund (grant ref. 2002/22). Conflict of interest declaration: None of the authors had any conflicts of interest. Authors' responsibilities: I.S.R. coordinated the study, developed the original hypotheses and undertook the writing of the manuscript and some of the analysis. K.N. undertook some of the analysis and assisted in the writing of the manuscript. P.M.E., D.B.D., A.R.C. and A.R.N. helped to develop the hypotheses and assisted in the writing of the manuscript. Acknowledgements: The authors are extremely grateful to all the families who took part in this study, the midwives for their help in recruiting them, and the whole ALSPAC team, which includes interviewers, computer and laboratory technicians, clerical workers, research scientists, volunteers, managers, receptionists and nurses.

\section{References}

1. Gao Y-T, Shu X-O, Dai Q et al. (2000) Associations of menstrual and reproductive factors with breast cancer risk: results from the Shanghai Breast Cancer Study. Int J Cancer 87, 295-300.
2. Hsieh CC, Trichopoulos D, Katsouyanni K et al. (1990) Age at menarche, age at menopause, height and obesity as risk factors for breast cancer: associations and interactions in an international case-control study. Int J Cancer 46, 796-800.

3. Kvale G \& Heuch I (1988) Menstrual factors and breast cancer risk. Cancer 62, 1625-1631.

4. Tavani A, Gallus S, La Vecchia C et al. (2001) Risk factors for breast cancer in women under 40 years. Eur J Cancer 35 , 1361-1367.

5. Butler L, Potischman N, Newman B et al. (2000) Menstrual risk factors and early onset breast cancer. Cancer Causes Control 11, 451-458.

6. Cooper G, Ephross S, Weinberg C et al. (1998) Menstrual and reproductive factors for ischaemic heart disease. Epidemiology 10, 255-259.

7. Fox K, Magaziner J, Sherwin R et al. (1993) Reproductive correlates of bone mass in elderly women. Study of Osteoporotic Fractures Research Group. J Bone Miner Res 8, 901-908.

8. Dreizen S, Spirakis C \& Stone R (1967) A comparison of skeletal growth and maturation in undernourished and well-nourished girls before and after menarche. J Pediatr 70, 256-263.

9. Satyarayana K \& Nadami Nadu A (1979) Nutrition and menarche in rural Hyderabad. Ann Hum Biol 2, 163-165.

10. Moisan J, Meyer F \& Gringras S (1990) A nested casecontrol study of the correlates of early menarche. Am J Epidemiol 132, 953-961.

11. Koprowski C, Ross R, Mack W et al. (1999) Diet, body size and menarche in a multiethnic cohort. Br J Cancer 79 , 1907-1911.

12. Petridou E, Syrigou E, Toupadaki N et al. (1996) Determinants of age at menarche as early life predictors of breast cancer risk. Int J Cancer 68, 193-198.

13. Maclure M, Travis L, Willett W et al. (1991) A prospective cohort study of nutrient intake and age at menarche. $A m J$ Clin Nutr 54, 649-656.

14. Merzenich H, Boenig H \& Wahrendorf J (1993) Dietary fat and sports activity as determinants for age at menarche. $\mathrm{Am}$ J Epidemiol 138, 217-224.

15. de Ridder C, Thijssen J, Van't Veer P et al. (1991) Dietary habits, sexual maturation and plasma hormones in pubertal girls: a longitudinal study. Am J Clin Nutr 54, 805-813.

16. Longcope C, Gorbach S, Goldin B et al. (1987) The effect of a low fat diet on estrogen metabolism. J Clin Endocrinol Metab 64, 1246-1250.

17. Goldin B, Adkercreutz H, Gorbach S et al. (1982) Estrogen excretion patterns and plasma levels in vegetarian and omnivorous women. $N$ Engl J Med 307, 1542-1547.

18. Adlercreutz H, Höckerstedt K, Bannwart C et al. (1987) Effect of dietary components, including lignans and phytoestrogens, on enterohepatic circulation and liver metabolism of estrogens and on sex hormone binding globulin (SHBG). J Steroid Biochem 27, 1135-1144.

19. Hughes R (1985) Intake of dietary fibre and the age of menarche. Ann Hum Biol 12, 325-332.

20. Lubin J, Burns P, Blot W et al. (1981) Dietary factors and breast cancer risk. Int J Cancer 28, 685-689.

21. Britton J, Wolff MS, Lapinski R et al. (2004) Characteristics of pubertal development in a multi-ethnic population of nine-year-old girls. Ann Epidemiol 14, 179-187.

22. Soriguer F, Gonzalez-Romero S, Esteva I et al. (1995) Does the intake of nuts and seeds alter the appearance of menarche? Acta Obstet Gynecol Scand 74, 455-461.

23. Sloboda D, Hart R, Doherty D et al. (2007) Age at menarche: influences of prenatal and postnatal growth. J Clin Endocrinol Metab 92, 46-50.

24. Dos Santos Silva I, De Stavola B, Mann V et al. (2002) Prenatal factors, childhood growth trajectories and age at menarche. Int J Epidemiol 31, 405-412. 
25. Golding J, Pembrey M, Jones R et al. (2001) ALSPAC - The Avon Longitudinal Study of Parents and Children I. Study methodology. Paediatr Perinat Epidemiol 15, 74-87.

26. Price GM, Paul AA, Key FB et al. (1995) Measurement of diet in a large national survey: comparison of computerised and manual coding of records in household measures. J Hum Nutr Diet 8, 417-428.

27. Holland B, Welch AA, Unwin ID et al. (1991) McCance $\&$ Widdowson's The Composition of Foods, 5th ed. Cambridge: The Royal Society of Chemistry.

28. Holland B, Unwin ID \& Buss DH (1988) Cereals and Cereal Products. Third Supplement to McCance \& Widdowson's The Composition of Foods (4th Edition). Cambridge: The Royal Society of Chemistry.

29. Holland B, Unwin ID \& Buss DH (1989) Milk Products and Eggs. Fourth Supplement to McCance \& Widdowson's The Composition of Foods (4th Edition). Cambridge: The Royal Society of Chemistry.

30. Holland B, Unwin ID \& Buss DH (1991) Vegetables, Herbs and Spices. Fifth Supplement to McCance \& Widdowson's The Composition of Foods (4th Edition). Cambridge: The Royal Society of Chemistry.

31. Holland B, Unwin ID \& Buss DH (1992) Fruit and Nuts. First Supplement to 5th Edition of McCance \& Widdowson's The Composition of Foods. Cambridge: The Royal Society of Chemistry.

32. Holland B, Welch AA \& Buss DH (1992) Vegetable Dishes. Second Supplement to 5th Edition of McCance \& Widdowson's The Composition of Foods. Cambridge: The Royal Society of Chemistry.

33. Holland B, Brown J \& Buss DH (1993) Fish and Fish Products. Third Supplement to 5th Edition of McCance E Widdowson's The Composition of Foods. Cambridge: The Royal Society of Chemistry.

34. Chan W, Brown J \& Buss DH (1994) Miscellaneous Foods Fourth Supplement to 5th Edition of McCance \& Widdowson's The Composition of Foods. Cambridge: The Royal Society of Chemistry.

35. Chan W, Brown J, Lee SM et al. (1995) Meat, Poultry and Game. Fifth Supplement to 5th Edition of McCance and Widdowson's The Composition of Foods. Cambridge: The Royal Society of Chemistry.

36. Chan W, Brown J, Church SM et al. (1996) Meat Products and Dishes. Sixth Supplement to 5th Edition of McCance $E$ Widdowson's The Composition of Foods. Cambridge: The Royal Society of Chemistry.
37. Willett W \& Stampfer M (1998) Implications of total energy intake for epidemiological analysis. In Nutritional Epidemiology, 2nd ed., pp. 273-297 [W Willett, editor]. New York: Oxford University Press.

38. Torun B (2005) Energy requirements of children and adolescents. Public Health Nutr 8, 968-993.

39. Rennie KL, Coward A \& Jebb SA (2007) Estimating underreporting of energy intake in dietary surveys using an individualised method. Br J Nutr 97, 1169-1176.

40. Bingham SA, Gill C, Welch A et al. (1994) Comparison of dietary assessments methods in nutritional epidemiology: weighed records $v .24 \mathrm{~h}$ recalls, food-frequency questionnaires and estimated-diet records. Br J Nutr $\mathbf{7 2}$, 619-643.

41. Cowin I, Emond A, Emmett P et al. (2001) Association between composition of the diet and haemoglobin and ferritin levels in 18-month-old children. Eur J Clin Nutr $\mathbf{5 5}$, 278-286.

42. Rogers IS, Gunnell D, Emmett PM et al. (2005) Crosssectional associations of diet and insulin-like growth factor levels in 7- to 8-year-old children. Cancer Epidemiol Biomarkers Prev 14, 204-212.

43. Berkey CS, Gardner J, Frazier AL et al. (2000) Relation of childhood diet and body size to menarche and adolescent growth in girls. Am J Epidemiol 152, 446-452.

44. Kralj-Cercek L (1956) The influence of food, body build, and social origin on the age at menarche. Hum Biol 4, 393-406.

45. Sanchez A, Kissinger D \& Phillips R (1981) A hypothesis on the etiological role of diet in menarche. Med Hypotheses 7 , 1339-1345.

46. Kissinger D \& Sanchez A (1987) The association of dietary factors with the age at menarche. Nutr Res 7, 471-479.

47. Ku S-Y, Kang J, Kim H et al. (2006) Age at menarche and its influencing factors in North Korean female refugees. Hum Reprod 21, 833-836.

48. Rosell M, Appleby P \& Key T (2005) Height, age at menarche, body weight and body mass index in life-long vegetarians. Public Health Nutr 8, 870-875.

49. Huddle J-M, Gibson R \& Cullinan T (1998) Is zinc a limiting nutrient in the diets of rural pregnant Malawian women? Br J Nutr 79, 257-265.

50. Bothwell $\mathrm{T}$ (2000) Iron requirements in pregnancy and strategies to meet them. Am J Clin Nutr 72, 1 Suppl., 257S-264S. 


\section{Appendix 1}

Spearman correlations ( $\rho$ ) between nutrient intakes obtained by FFQ and 3 d food record at 3 years (450 boys, 360 girls)

\begin{tabular}{|c|c|c|c|c|c|}
\hline \multirow[b]{2}{*}{ Nutrient } & \multirow[b]{2}{*}{ Sex } & \multicolumn{2}{|c|}{ Absolute nutrient intakes } & \multicolumn{2}{|c|}{ Nutrient intakes per MJ } \\
\hline & & $\rho$ & $P$ value & $\rho$ & $P$ value \\
\hline \multirow[t]{2}{*}{ Energy (MJ) } & Boys & $0 \cdot 116$ & 0.014 & NA & - \\
\hline & Girls & $0 \cdot 195$ & $<0.001$ & NA & - \\
\hline \multirow[t]{2}{*}{ Total fat (g) } & Boys & 0.216 & $<0.001$ & 0.382 & $<0.001$ \\
\hline & Girls & 0.211 & $<0.001$ & 0.295 & $<0.001$ \\
\hline \multirow{2}{*}{ SFA (g) } & Boys & 0.272 & $<0.001$ & 0.442 & $<0.001$ \\
\hline & Girls & 0.293 & $<0.001$ & 0.332 & $<0.001$ \\
\hline \multirow[t]{2}{*}{ PUFA (g) } & Boys & 0.260 & $<0.001$ & 0.262 & $<0.001$ \\
\hline & Girls & 0.235 & $<0.001$ & 0.313 & $<0.001$ \\
\hline \multirow[t]{2}{*}{ Carbohydrate (g) } & Boys & 0.055 & 0.248 & 0.355 & $<0.001$ \\
\hline & Girls & 0.211 & $<0.001$ & 0.320 & $<0.001$ \\
\hline \multirow[t]{2}{*}{ Sugar (g) } & Boys & $0 \cdot 151$ & 0.001 & 0.332 & $<0.001$ \\
\hline & Girls & $0 \cdot 177$ & 0.001 & 0.237 & $<0.001$ \\
\hline \multirow[t]{2}{*}{$\mathrm{Fe}(\mathrm{mg})$} & Boys & $0 \cdot 198$ & $<0.001$ & 0.448 & $<0.001$ \\
\hline & Girls & 0.209 & $<0.001$ & 0.234 & $<0.001$ \\
\hline \multirow[t]{2}{*}{ Zn (mg) } & Boys & 0.295 & $<0.001$ & 0.371 & $<0.001$ \\
\hline & Girls & $0 \cdot 261$ & $<0.001$ & 0.327 & $<0.001$ \\
\hline \multirow[t]{2}{*}{$\mathrm{Ca}(\mathrm{mg})$} & Boys & 0.363 & $<0.001$ & 0.548 & $<0.001$ \\
\hline & Girls & 0.399 & $<0.001$ & 0.476 & $<0.001$ \\
\hline \multirow[t]{2}{*}{$\mathrm{K}(\mathrm{mg})$} & Boys & $0 \cdot 278$ & $<0.001$ & 0.377 & $<0.001$ \\
\hline & Girls & 0.294 & $<0.001$ & 0.360 & $<0.001$ \\
\hline \multirow[t]{2}{*}{ Vitamin C (mg) } & Boys & 0.474 & $<0.001$ & 0.494 & $<0.001$ \\
\hline & Girls & 0.499 & $<0.001$ & 0.508 & $<0.001$ \\
\hline \multirow[t]{2}{*}{ Thiamin (mg) } & Boys & 0.248 & $<0.001$ & $0 \cdot 241$ & $<0.001$ \\
\hline & Girls & 0.217 & $<0.001$ & 0.198 & $<0.001$ \\
\hline \multirow[t]{2}{*}{ Riboflavin (mg) } & Boys & 0.336 & $<0.001$ & 0.402 & $<0.001$ \\
\hline & Girls & 0.337 & $<0.001$ & 0.390 & $<0.001$ \\
\hline \multirow[t]{2}{*}{ Folate $(\mu \mathrm{g})$} & Boys & 0.259 & $<0.001$ & 0.365 & $<0.001$ \\
\hline & Girls & 0.274 & $<0.001$ & 0.263 & $<0.001$ \\
\hline \multirow[t]{2}{*}{ Vitamin D $(\mu \mathrm{g})$} & Boys & $0 \cdot 177$ & $<0.001$ & $0 \cdot 227$ & $<0.001$ \\
\hline & Girls & 0.207 & $<0.001$ & 0.208 & $<0.001$ \\
\hline \multirow[t]{2}{*}{ Retinol equivalents $(\mu \mathrm{g})$} & Boys & 0.336 & $<0.001$ & 0.414 & $<0.001$ \\
\hline & Girls & 0.309 & $<0.001$ & 0.374 & $<0.001$ \\
\hline \multirow[t]{2}{*}{ Vitamin E (mg) } & Boys & $0 \cdot 198$ & $<0.001$ & $0 \cdot 215$ & $<0.001$ \\
\hline & Girls & 0.260 & $<0.001$ & 0.308 & $<0.001$ \\
\hline
\end{tabular}

NA, not applicable.

\section{Appendix 2}

Spearman correlations ( $\rho$ ) between nutrient intakes from food records and FFQ in 7-year-old children (n 730$)$

\begin{tabular}{|c|c|c|c|c|}
\hline \multirow[b]{2}{*}{ Nutrient } & \multicolumn{2}{|c|}{ Absolute nutrient intakes } & \multicolumn{2}{|c|}{ Nutrient intakes per MJ } \\
\hline & $\rho$ & $P$ value & $\rho$ & $P$ value \\
\hline $\mathrm{Ca}$ & 0.402 & $<0.001$ & 0.453 & $<0.001$ \\
\hline Carotene & 0.338 & $<0.001$ & 0.309 & $<0.001$ \\
\hline Cholesterol & 0.292 & $<0.001$ & 0.358 & $<0.001$ \\
\hline Fat & 0.251 & $<0.001$ & 0.352 & $<0.001$ \\
\hline $\mathrm{Fe}$ & 0.204 & $<0.001$ & 0.299 & $<0.001$ \\
\hline Folate & 0.212 & $<0.001$ & 0.294 & $<0.001$ \\
\hline lodine & 0.380 & $<0.001$ & 0.403 & $<0.001$ \\
\hline K & $0 \cdot 208$ & $<0.001$ & 0.306 & $<0.001$ \\
\hline Energy & $0 \cdot 178$ & $<0.001$ & NA & - \\
\hline $\mathrm{Mg}$ & 0.281 & $<0.001$ & 0.406 & $<0.001$ \\
\hline MUFA & 0.209 & $<0.001$ & $0 \cdot 261$ & $<0.001$ \\
\hline $\mathrm{Na}$ & 0.227 & $<0.001$ & 0.200 & $<0.001$ \\
\hline NSP & 0.346 & $<0.001$ & 0.463 & $<0.001$ \\
\hline $\mathrm{P}$ & 0.314 & $<0.001$ & 0.414 & $<0.001$ \\
\hline PUFA & $0 \cdot 171$ & $<0.001$ & 0.174 & $<0.001$ \\
\hline Protein & 0.213 & $<0.001$ & 0.319 & $<0.001$ \\
\hline Retinol & 0.376 & $<0.001$ & 0.392 & $<0.001$ \\
\hline
\end{tabular}


Appendix 2 Continued

\begin{tabular}{|c|c|c|c|c|}
\hline \multirow[b]{2}{*}{ Nutrient } & \multicolumn{2}{|c|}{ Absolute nutrient intakes } & \multicolumn{2}{|c|}{ Nutrient intakes per MJ } \\
\hline & $\rho$ & $P$ value & $\rho$ & $P$ value \\
\hline Retinol equivalents & 0.333 & $<0.001$ & 0.303 & $<0.001$ \\
\hline Riboflavin & 0.346 & $<0.001$ & 0.431 & $<0.001$ \\
\hline SFA & 0.245 & $<0.001$ & 0.300 & $<0.001$ \\
\hline Sugar & $0 \cdot 228$ & $<0.001$ & 0.320 & $<0.001$ \\
\hline Thiamin & $0 \cdot 139$ & $<0.001$ & $0 \cdot 163$ & $<0.001$ \\
\hline Vitamin C & $0 \cdot 422$ & $<0.001$ & 0.463 & $<0.001$ \\
\hline Vitamin D & 0.254 & $<0.001$ & $0 \cdot 260$ & $<0.001$ \\
\hline Vitamin E & 0.256 & $<0.001$ & 0.226 & $<0.001$ \\
\hline $\mathrm{Zn}$ & 0.268 & $<0.001$ & 0.321 & $<0.001$ \\
\hline
\end{tabular}

NA, not applicable. 